\title{
EVALUATING THE EFFICIENCY AND RESISTANCE TOWARDS THE ABIOTIC FACTORS IN THE NEWLY BRED VARIETIES OF THE CEREAL CROPS
}

\author{
${ }^{1}$ Hamlet Martirosyan, ${ }^{2}$ Marine Hovhannisyan, ${ }^{3}$ Mariam Abovyan \\ ${ }^{1}$ Associate Professor, Department of Plant Growing and Soil Science, \\ Candidate of agricultural sciences, Armenian National Agrarian University \\ ${ }^{2}$ Researcher, Research Center of Armenian National Agrarian University \\ ${ }^{3}$ Master, Armenian National Agrarian University
}

DOI: 10.46609/IJAER.2020.v06i01.004 URL: https://doi.org/10.46609/IJAER.2020.v06i01.004

\begin{abstract}
New varietal samples of cereals (wheat-rye, barley, emmer) obtained at the Research Center of the Plant Gene pool and selection of the Armenian National Agrarian University were tested in arid and rainfed zones of the Republic of Armenia. Wild forms of wheat and barley served as the paternal form for obtaining the varietal samples.

As a result of research, it was found that the yield of the obtained varietal samples under arid conditions exceeded the traditionally cultivated in these zones varieties of wheat-rye, barley and emmer, by $8.1 ; 9.2 ; 7.7 \mathrm{~kg} / \mathrm{ha}$, respectively. Their introduction into production can be extremely important on the way to solving the problem of climate change in the context of global warming, and provide high profits for farmers.
\end{abstract}

Keywords: Wheat-rye, Barley, Emmer, Variety, Abiotic factors, Cereal crops, Irrigated and unirrigated lands, Climate change, High efficiency.

\section{INTRODUCTION}

Breeding of the new and highly efficient agricultural crop varieties which are most resistant towards the stressful situations caused by the global climate changes is of paramount importance for meeting the increasing demand of the population for food, providing feed for the livestock sector and for solving the issues in agri-food system on the whole. 
International Journal of Agriculture and Environmental Research

ISSN: 2455-6939

Volume: 06, Issue: 01 "January-February 2020"

Growing under the conditions of the changed climate the crops become stricken with various water and thermal stresses, which deprive the crops of the opportunity to manifest their potential yielding capacities. In this respect the role of selective varieties, which have been bred through the participation of the parental forms and are endowed with high resistance rate towards the pests and diseases and to various stressful situations [2,3], is extremely important.

Similar valuable properties and features are observed in some cereal crop varieties bred at the research center of Plants Selection and Genofond, which have inherited the mentioned properties from their wild parental forms. It is worth mentioning that Armenia is rich in the wild cereal crop varieties, which come forth as a valuable selection source material distinguished by such characteristic traits as high rate of frost-, drought-resistance, high protein content in a grain, etc. From this perspective the crop varieties, which have been bred in the result of the crossbreeding with the wild crop varieties, are highly evaluated. These are the two emmer varieties (Garni, Zvartnots) and a barley variety (Araratyan), which is a multiple-row crop and is mostly peculiar to the winter barley species, for which the wild emmer (Triticum. dicoccoides Koern) and bulbous barley (Hordeum bulbosum L.)[1] have served as wild parental forms. The wheat-rye variety "Tchyughavor" bred through analytic selection method at the abovementioned research center is of no less importance. The latter can be of great significance as the best source for grain and green fodder.

Scientific investigations have been conducted on the mentioned varieties to disclose whether those valuable properties are fixed and sustainable in the plants' genotypes. The mentioned researches went on throughout the vegetation year of 2018-2019 in 2 zones, namely in the irrigated lands of the Edjmiatsin province at the Armavir region and in the pre-mountainous dry lands of the Abovyan province at the Kotayk region. The mentioned investigations were aimed at the disclosure of the resistance rate of those variety samples to the water stress. In the extreme situation of the irrigation water shortage the relocation of the cereal plantations from the irrigated lowlands to the dry areas of pre-mountainous zones and the provision of high efficiency of stress-resistant varieties can be a relevant solution for such urgent and actual issue.

Sowing of the wheat-rye variety "Tchyughavor" was carried out in the second ten days of September and October (in the Kotayk and Armavir regions), while the barley variety "Araratyan" and emmer varieties "Garni" and "Zvartnots" were sown in the third and first ten days of March respectively. Before planting 25 t/ha manure and phosphoric-potash fertilizers per $\mathrm{P}_{90} \mathrm{~K}_{60}$ active agent were introduced under the deep plowing as the main fertilizers. In spring during the bush formation period the plants were provided with $\mathrm{N}_{70}$ nitrogen. Planting was implemented with the same dose of $\mathbf{5 , 0} \mathbf{~ m l n} / \mathbf{g e r m}$ grain for all variety samples. The planting dose has been chosen with relatively lower indices, so as the plants could have the best 
conditions for air and soil nutrition, which would promote the increase of potential yield capacity.

Similar conditions for all varieties have been created and the treatment activities have been implemented at the same time upon the same principle. When following the plant growing process it becomes vivid that in the dry pre-mountainous conditions the maturation phase in the barley and emmer varieties has been delayed for almost a month (10.08-17.08.2019) as compared to the sowings at Armavir region (14.07-19.07.2019), while this discrepancy in the wheat-rye has made only 9 days (table 1).

Table 1: Results of phenological observations in the studied regions

\begin{tabular}{|c|c|c|c|c|c|c|c|c|}
\hline \multirow[b]{2}{*}{ Crop } & \multicolumn{7}{|c|}{ Growth and development phases } & \multirow[b]{2}{*}{ 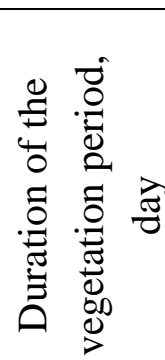 } \\
\hline & . & 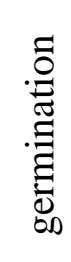 & 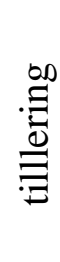 & .0 & $\frac{a}{0}$ & 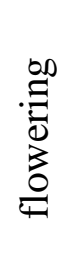 & 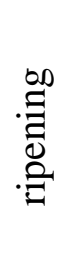 & \\
\hline \multicolumn{9}{|c|}{ Armavir marz } \\
\hline $\begin{array}{l}\text { Wheat-rye } \\
\text { "Armenian } \\
\text { Tchyughavor" }\end{array}$ & $\underset{0}{\infty}$ & 递 & $\stackrel{\infty}{=}$ & 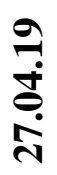 & $\begin{array}{l}\frac{9}{10} \\
\hat{0}\end{array}$ & $\begin{array}{l}\hat{\sigma} \\
\dot{\theta} \\
\dot{\theta}\end{array}$ & $\frac{a}{\hat{\sigma}}$ & 268 \\
\hline Barley "Araratyan" & $\begin{array}{l}\stackrel{\theta}{\ddot{\theta}} \\
\ddot{\theta} \\
\dot{\theta}\end{array}$ & 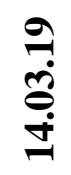 & ஜें & 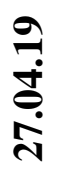 & $\underset{0}{0}$ & י & $\begin{array}{l}\frac{a}{5} \\
\hat{\theta} \\
\dot{I}\end{array}$ & 122 \\
\hline $\begin{array}{l}\text { Emmer } \\
\text { "Zvartnots" }\end{array}$ & $\begin{array}{l}\stackrel{\theta}{\ddot{\theta}} \\
\ddot{\theta} \\
\dot{\theta}\end{array}$ & ڤે̣ & $\begin{array}{l}\stackrel{\theta}{7} \\
\dot{d} \\
\dot{d}\end{array}$ & $\begin{array}{l}\hat{0} \\
\hat{0} \\
0 \\
0 \\
0\end{array}$ & $\frac{a}{\dot{\theta}}$ & $\begin{array}{l}\stackrel{\theta}{0} \\
\dot{0} \\
\dot{\theta}\end{array}$ & $\begin{array}{l}\frac{a}{5} \\
\text { å }\end{array}$ & 129 \\
\hline Emmer "Garni" & 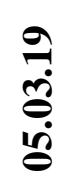 & ڤે & 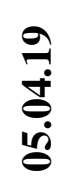 & $\frac{9}{10}$ & 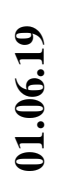 & $\frac{a}{\dot{\theta}}$ & $\frac{a}{\hat{0}}$ & 129 \\
\hline
\end{tabular}


International Journal of Agriculture and Environmental Research

ISSN: 2455-6939

Volume: 06, Issue: 01 "January-February 2020"

\begin{tabular}{|c|c|c|c|c|c|c|c|c|}
\hline $\begin{array}{l}\text { Wheat-rye } \\
\text { "Armenian } \\
\text { Tchyughavor" }\end{array}$ & 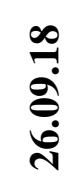 & $\stackrel{\infty}{\stackrel{\infty}{\leftrightarrows}}$ & $\frac{\infty}{\stackrel{\infty}{0}}$ & $\begin{array}{l}\stackrel{2}{\circ} \\
\stackrel{0}{\circ} \\
\stackrel{8}{8}\end{array}$ & $\begin{array}{l}\overrightarrow{0} \\
\stackrel{0}{0} \\
\stackrel{0}{0}\end{array}$ & 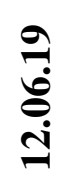 & $\begin{array}{l}\frac{a}{1} \\
\text { ลें }\end{array}$ & 292 \\
\hline Barley "Araratyan" & 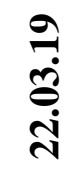 & $\begin{array}{l}\stackrel{\oplus}{\oplus} \\
\stackrel{\oplus}{\oplus}\end{array}$ & 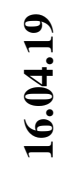 & 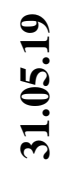 & ڤે & , & $\begin{array}{l}\stackrel{\theta}{0} \\
\stackrel{0}{0} \\
\stackrel{0}{0}\end{array}$ & 134 \\
\hline $\begin{array}{l}\text { Emmer } \\
\text { "Zvartnots" }\end{array}$ & 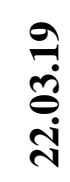 & $\begin{array}{l}\overrightarrow{7} \\
\text { ثे } \\
\text { İ }\end{array}$ & $\frac{a}{\dot{\vec{d}}}$ & $\begin{array}{c}\frac{0}{8} \\
\stackrel{8}{8} \\
\qquad\end{array}$ & 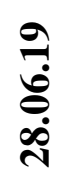 & $\begin{array}{c}\frac{2}{5} \\
\qquad \\
0\end{array}$ & 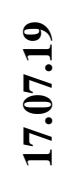 & 138 \\
\hline Emmer "Garni" & 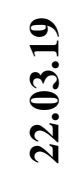 & 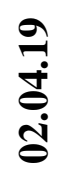 & $\begin{array}{l}\frac{a}{\dot{J}} \\
\dot{\vec{d}}\end{array}$ & $\begin{array}{l}\frac{0}{8} \\
\stackrel{0}{0}\end{array}$ & 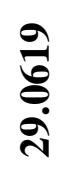 & $\begin{array}{l}\frac{2}{5} \\
\stackrel{5}{0}\end{array}$ & $\begin{array}{l}\stackrel{a}{0} \\
\stackrel{0}{0} \\
\text { ì }\end{array}$ & 139 \\
\hline
\end{tabular}

Based on those indicators the duration of vegetation period of the mentioned variety samples has been calculated and it has been found out that in Armavir it makes 122-129 days, while in Kotayk it is prolonged making 134-139 days and for wheat-rye it has fluctuated within 268-292 days.

When describing the advantages of tested variety samples it is very important to evaluate their efficiency, resistance indices to the environmental factors, morphological properties, as well as their resistance to diseases [5]. The results of the corresponding investigations are summed up in table 2. 
International Journal of Agriculture and Environmental Research

ISSN: 2455-6939

Volume: 06, Issue: 01 "January-February 2020"

Table 2: Indicators of efficacy and tolerance to the abiotic factors of the tested varieties in the studied regions

\begin{tabular}{|c|c|c|c|c|c|c|c|c|}
\hline \multirow[b]{2}{*}{ Crop } & \multirow[b]{2}{*}{ 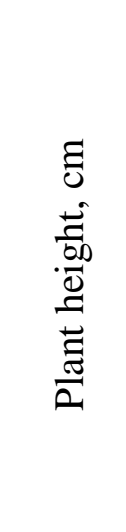 } & \multicolumn{2}{|c|}{ Tillering } & \multirow{2}{*}{ 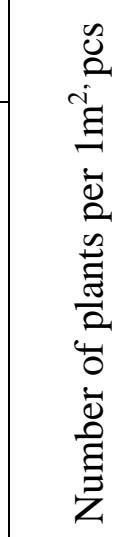 } & \multirow{2}{*}{ 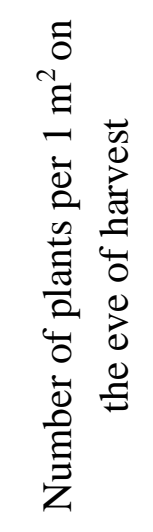 } & \multirow[b]{2}{*}{ 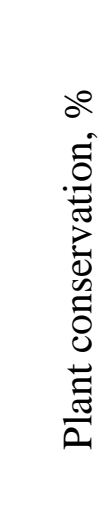 } & \multirow[b]{2}{*}{ 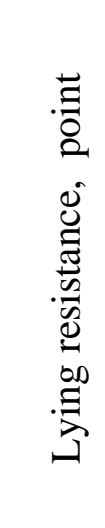 } & \multirow[b]{2}{*}{ 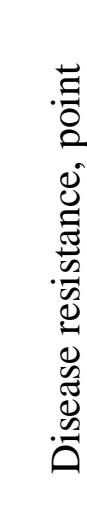 } \\
\hline & & 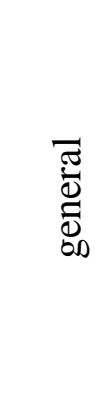 & 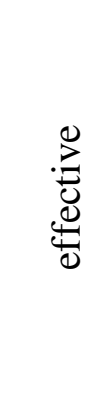 & & & & & \\
\hline \multicolumn{9}{|c|}{ Armavir marz } \\
\hline $\begin{array}{l}\text { Wheat-rye } \\
\text { "Armenian } \\
\text { Tchyughavor" }\end{array}$ & 197.8 & 2.6 & 1.1 & 453 & 409.1 & 90.3 & 5.0 & 5.0 \\
\hline $\begin{array}{l}\text { Barley } \\
\text { "Araratyan" }\end{array}$ & 79.5 & 2.4 & 1.1 & 462 & 426.1 & 92.4 & 5.0 & 5.0 \\
\hline $\begin{array}{l}\text { Emmer } \\
\text { "Zvartnots" }\end{array}$ & 69.4 & 2.0 & 1.0 & 457 & 428.0 & 93.7 & 4.0 & 4.0 \\
\hline Emmer "Garni" & 73.2 & 2.1 & 1.0 & 447 & 413.4 & 92.5 & 5.0 & 5.0 \\
\hline \multicolumn{9}{|c|}{ Kotayq marz (unirrigated) } \\
\hline $\begin{array}{l}\text { Wheat-rye } \\
\text { "Armenian } \\
\text { Tchyughavor" }\end{array}$ & 181.5 & 2.2 & 1.03 & 441.2 & 369.8 & 83.7 & 5.0 & 5.0 \\
\hline $\begin{array}{l}\text { Barley } \\
\text { "Araratyan" }\end{array}$ & 71.3 & 2.0 & 1.02 & 444.1 & 402.8 & 90.7 & 5.0 & 4.5 \\
\hline $\begin{array}{l}\text { Emmer } \\
\text { "Zvartnots" }\end{array}$ & 61.4 & 1.7 & 1.07 & 439.2 & 392.9 & 89.5 & 4.5 & 4.5 \\
\hline Emmer "Garni" & 68.7 & 1.8 & 1.05 & 434.4 & 394.8 & 90.9 & 5.0 & 5.0 \\
\hline
\end{tabular}

Regarding the plants' height the wheat-rye records $198 \mathrm{~cm}$ height and in dry conditions it makes $181.5 \mathrm{~cm}$, which is a rather high indicator for such conditions. In case of its cultivation for green mass it can provide up to $450 \mathrm{c} / \mathrm{ha}$ yield, while the barley and emmer have been marked out with their short stalks in both zones with the height of $61.4-79.0 \mathrm{~cm}$. 
International Journal of Agriculture and Environmental Research

ISSN: 2455-6939

Volume: 06, Issue: 01 "January-February 2020"

The overall bush formation in wheat-rye has made 2.6-2.2 in the irrigated and dry conditions, besides in irrigated conditions the bushing size has exceeded that of observed in the dry condition only by 0.4 . It is a very vital qualitative index particularly for the forage crops used for green fodder, like, for instance, wheat-rye, which is the primary guarantee for the expected high yield of the green mass.

By following the plants survival process during the vegetation period it has become clear that it is rather high and has ensured reliable indices. In this view the winter wheat-rye considerably lags behind the spring cereals (barley, emmer) in both zones, which is surely predictable and real. In order to determine the winter-hardiness of the wheat-rye, monoliths method has been applied, since there was little snow in the winter of 2018 and in this regard more stressful conditions were established for the plants [4]. As a result, it has been found out that this wheatrye variety has provided $94.1 \%$ winter-hardiness in irrigated conditions and in dry conditions it is lower by $3.1 \%(91.0 \%)$.

On the whole, when evaluating the variety samples a great stress is put on the plants behavior in the resulted undesired, stressful conditions for the plants growth. In this regard the plants resistance, especially in the dry conditions, has been determined through the creation of artificial covers and, as a result, it has been disclosed, that in the dry conditions of pre-mountainous zones, when the air temperature exceeds $30^{\circ} \mathrm{C}$ and only $385 \mathrm{~mm}$ precipitation is fallen during the vegetation period (according to the data of meteorological station of the Kotayk region) the regular turgor state in plants (particularly in barley and emmer) is preserved. This extremely vital property has been inherited by the plants from their wild parental forms. The same interpretation can be true about the high resistance of the variety samples towards the diseases. During the trials, in the experimental plots provided for all variety samples the principle of artificial infestation of the plants with various fungal diseases has been applied, and in the result it has been found out, that the plants have shown a rather high resistance; only in the emmer variety "Zvartnots" at Armavir region and in the emmer variety "Zvartnots and barley variety "Araratyan" at Kotayk region small traces of leaf rust have been observed. For these varieties the resistance to the diseases has been assessed with 4 and for the other varieties with 5 points.

The bending phenomenon in the cereals is also undesired, which makes the grain filling process significantly difficult and the grain quality falls down. As a result of the investigations it becomes clear that in Armavir region except from the emmer variety "Zvartnots" which has been assessed with 4 points, the other variety samples are rather resistant and have been assessed with 5 points; in Kotayk region the emmer variety has been assessed with 4 points and the wheat-rye variety, despite the significant height $(185-200 \mathrm{~m})$ of its stalk, is rather resistant towards bending and has been assessed with 4.7 points (in some plants this phenomenon was slightly observed). 
International Journal of Agriculture and Environmental Research

ISSN: 2455-6939

Volume: 06, Issue: 01 "January-February 2020"

Analysis of the yield structural elements has been conducted on the samples taken from the experimental plots (Edjmiatsin and Kotayk) on the eve of the harvesting day. The results of the mentioned analysis are introduced in table 3.

Table 3: Results of structural element analysis

\begin{tabular}{|c|c|c|c|c|c|c|c|c|}
\hline \multirow[b]{2}{*}{ Crop } & \multirow[b]{2}{*}{ 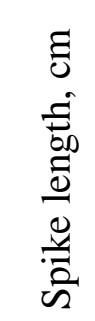 } & \multicolumn{3}{|c|}{ of 1 spike } & \multicolumn{2}{|c|}{ on $1 \mathrm{~m}^{2}$} & \multirow[b]{2}{*}{ 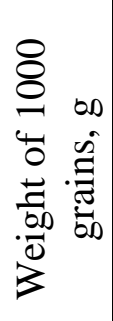 } & \multirow[b]{2}{*}{ 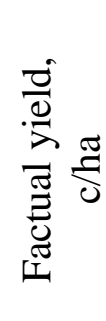 } \\
\hline & & 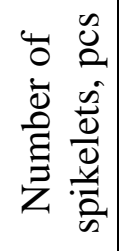 & 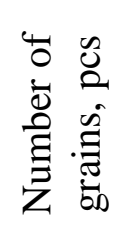 & 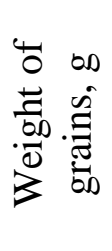 & 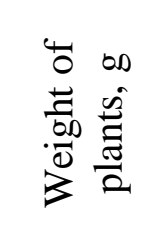 & 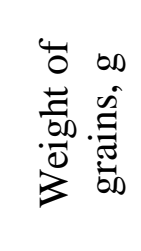 & & \\
\hline \multicolumn{9}{|c|}{ Armavir marz } \\
\hline $\begin{array}{l}\text { Wheat-rye } \\
\text { "Armenian } \\
\text { Tchyughavor" }\end{array}$ & 11.5 & 22.3 & 58.1 & 2.9 & 1390.0 & 1130.0 & 50.1 & 52.9 \\
\hline $\begin{array}{l}\text { Barley } \\
\text { "Araratyan" }\end{array}$ & 8.3 & 58.2 & 42.0 & 1.6 & 880.0 & 716.3 & 38.5 & 32.1 \\
\hline $\begin{array}{l}\text { Emmer } \\
\text { "Zvartnots" }\end{array}$ & 7.2 & 12.7 & 26.7 & 0.9 & 462.2 & 385.2 & 33.7 & 22.1 \\
\hline $\begin{array}{l}\text { Emmer } \\
\text { "Garni" }\end{array}$ & 5.9 & 10.9 & 24.5 & 0.8 & 396.8 & 330.7 & 32.6 & 20.7 \\
\hline \multicolumn{9}{|c|}{ Kotayq marz (unirrigated) } \\
\hline $\begin{array}{l}\text { Wheat-rye } \\
\text { "Armenian } \\
\text { Tchyughavor" }\end{array}$ & 10.1 & 20.1 & 49.8 & 2.3 & 1021.3 & 851.4 & 46.2 & 38.1 \\
\hline $\begin{array}{l}\text { Barley } \\
\text { "Araratyan" }\end{array}$ & 7.8 & 51.2 & 39.7 & 1.4 & 691.5 & 578.4 & 35.8 & 27.1 \\
\hline $\begin{array}{l}\text { Emmer } \\
\text { "Zvartnots" }\end{array}$ & 6.4 & 10.9 & 21.5 & 0.7 & 345.5 & 295.1 & 32.7 & 18.8 \\
\hline $\begin{array}{l}\text { Emmer } \\
\text { "Garni", }\end{array}$ & 5.0 & 8.9 & 22.6 & 0.7 & 354.8 & 288.2 & 30.9 & 16.3 \\
\hline
\end{tabular}

As a result of the investigations it has been found out that the length of wheat-rye spike/ear fluctuates within 10.1-14.5 cm; in the irrigated conditions (Edjmiatsin) the barley variety has recorded a spike length $(9.3 \mathrm{~cm})$ peculiar to the genotype of its maternal form, which, anyhow, in the dry conditions (Kotayk) has decreased by $0.5 \mathrm{~cm}$ falling down to $8.8 \mathrm{~cm}$, while the emmer varieties have developed the shortest spikes -5.0-7.2 cm- keeping the decreasing tendency of the spike/ear length in the dry conditions, like in the previous cases. The spike/ear length has had its significant impact on the spikelets formed in the ear, as well as on the number and weight of the 
International Journal of Agriculture and Environmental Research

ISSN: 2455-6939

Volume: 06, Issue: 01 "January-February 2020"

grains developed in an ear. In the ear/spike of the wheat-rye 58.1-49.8 grains have averagely developed, besides, in the dry conditions the number of grains has decreased by 8.3 items in the relatively shorter spikes. This regularity held true both in case of barley and emmer varieties, anyhow, in the first case the discrepancy has made only 2.3 grains, while in the emmer varieties it fluctuates within the range of 4.2-1.9 grains. Here it is worth mentioning that in the ear/spike of the barley variety, unlike its maternal form, a significant increase in the grain number has been observed, which is related to the functions taking place throughout the crossbreeding and to the correct selection of the paternal form. The weight of the grains in an ear has been also determined, which is the main indicator of the biological yield and it is greatly related to both the ear length and the number of grains in an ear. Depending the weather and irrigation conditions of the experimental year, this indicator fluctuates strongly as well, which makes respectively 0.6, 0.2 for the wheat-rye, while for the barley and emmer it is 0.1 and $0.2 \mathrm{~g}$.

The weight of 1000 grains is also of paramount importance, which is related to the grain size and has a great impact on the resulted yield amount. This indicator has been greatly influenced by the cultivation conditions as well, since in case of cultivating the wheat-rye in dry conditions the mentioned indicator has decreased by $3.9 \mathrm{~g}$ swinging down from the 50.1 to $46.2 \mathrm{~g}$. The same regularity is observed in the other cereal crop varieties as well. For example, in the barley variety of "Araratyan" this indicator has decreased by $2.7 \mathrm{~g}$ (from $38.5 \mathrm{~g}$ to $35.8 \mathrm{~g}$ ) in the dry conditions, while in the emmer varieties it fluctuates within the range of 1.0-1.7 g. Despite the aforementioned the experimental variety samples have provided sufficient yield (table 3), which makes 20.1-22.1 c/ha (irrigated) and 16.3-18.8 c/ha (dry) in the emmer varieties, while in the barley and wheat-rye varieties it has made $32.1,27.1 \mathrm{c} / \mathrm{ha}$ and $52.9,38.1 \mathrm{c} / \mathrm{ha}$ respectively.

It is noteworthy that the common varieties of the experimented crops demonstrate 18-21\% lower grain yield both in the irrigated and dry conditions as compared to that of the investigated variety samples. The yield amount of the wheat-rye, barley and emmer varieties exceeds the cultivated common varieties (dry conditions) by 8.1, 9.2 and $7.7 \mathrm{c} /$ ha respectively.

After passing through the State Variety Trials the new cereal crop varieties bred at the research centre can further come forth as rather perspective, well-established and valuable varieties, which can be best adapted to the stressful situations caused by the climate change and provide extra income to the farm households.

\section{REFERENCES}

1. Harutyunyan M.G., Martirosyan H.S., Hovhannisyan M.Ts. - The role of wild relatives in cereal crop breeding. Bulletin of AAA, Materials of International Conference, Yerevan, 2003, 3-4. 
2. Guzhov Yu.L. - Selection and seed breeding of cultivated plants. M. Kolos, 2003, 536 p.

3. Zhuchenko A.A. Opportunities of creating plant varieties and hybrids taking into account climate change // Strategy for adaptive selection of field crops with regard to global climate changes. Saratov, 2004, 2, pp. 10-16.

4. Ashraf M., Ozturk M. \& Athar H.R. Salinity and Water Stress. Improving Crop Efficiency. Springer-Verlag, Berlin, 2009.

5. Murphy D. Plant breeding and biotechnology. United Kingdom. Cambridge University Press, 2007. 